\title{
Factors Affecting the Adoption of Global Sourcing: A Case Study of Tuskys Supermarkets, Kenya
}

\author{
Paul Ndegwa Magenda ${ }^{1}$, and Mike Amuhaya Iravo $^{2}$ \\ ${ }^{1}$ (Master's Student, Department of Entrepreneurship and Procurement in the School of Human Resource \\ Development, Jomo Kenyatta University of Agriculture and Technology, Kenya) \\ ${ }^{2}$ (Lecturer, Department of Entrepreneurship and Procurement in the School of Human Resource Development, \\ Jomo Kenyatta University of Agriculture and Technology, Kenya)
}

\begin{abstract}
Due to the changing market conditions, intensified global competition, and radical change in technology, pressure to improve is severe and relentless in business world. In the wake of such, global sourcing is proving a strategic weapon in establishing efficient supply chain, cutting costs, improving quality, and spurring innovation. This study is about factors affecting the adoption of global sourcing, a case study of Tuskys supermarkets in Kenya. The results of this study confirm the significant influence of four utmost important factors on adoption of global sourcing namely currency fluctuation, complex logistics, tariffs and non-tariff barriers, as well as culture and language differences. It examines these four factors, and finds out that adoption of global sourcing is not effective due to varying factors, including and not limited to complicated logistics, currency fluctuations, and the tariff and non-tariff barriers in varying degrees. The study further reveals that there is no universal compass to pursue global sourcing. The companies that succeed will be the ones that have learned how to leverage and coordinate their activities on a worldwide basis. Tuskys supermarkets have to deal with those factors in the light of different scenarios, practical aspects and challenges, in order to match global competitiveness as well as attain the desired results in adopting global sourcing.
\end{abstract}

Keywords: Complicated logistics, culture and language differences, currency fluctuation, global sourcing, tariffs and non-tariff barriers.

\section{Introduction}

Global economic integration in $21^{\text {st }}$ century, has facilitated the rational allocation of worldwide resources, and is also the direct driving force for global sourcing and supply chain integration. One area in which globalization has moved from concept to practice is global sourcing. Global sourcing is an advanced approach to sourcing and supply management that involves integrating and coordinating common materials, processes, designs, technologies and suppliers across worldwide buying, design and operating locations (Monczka and Trent, 1991). Since most organizations do not have well-developed global sourcing strategies in place, improvement opportunities in this area are attractive and as yet largely unrealized. Shifting from a narrow cost-reduction emphasis to an emphasis on globally integrated and coordinated sourcing strategies should improve an organization's competitiveness.

The progression from domestic buying to international purchasing and then to global sourcing can be visualized as movement along a continuum through different levels. In moving from domestic purchasing to international purchasing, organizations must contend with longer distances, increased rules and regulations, currency fluctuations, customs requirements, and language, cultural and time differences. To curb rising production costs and to boost global competitiveness, many companies are turning to global sourcing as part of their production to overseas countries.

With the coming of boarderless economy, we can now overview which area is most optimal to purchase by quality, cost, delivery, and engineering capability. We can watch the cost disparity by each countries using computer information data base. Although exchange rate and currency evaluation are still unstable, observing these data can show the best response and new choices of exchange rate free purchasing (Shimokawa, 2000). Global sourcing can provide significant benefits if organizations have a bona-fide plan, commit the required level of resources, and are patient in receiving initial benefits.

\section{Literature Review}

Global sourcing entails strategic procurement with an international focus. It is the process of identifying, developing and utilizing the best source of supply for the enterprise, regardless of location. In a more recent study Trent and Monczka (2005) identified five levels of emergence towards global sourcing that most organizations follow. In Level 1, organization does domestic buying but often progressing toward international purchasing because of a lack of suitable domestic suppliers. In Level 2, there is international purchasing usually limited or performed on an ad hoc or reactive basis. 
In Level 3, the organization is making international purchasing part of the firm's sourcing strategy but the strategies are not well coordinated across worldwide buying sites and usually focus on price improvements. In Level 4, organization requires worldwide information systems, personnel with advanced knowledge and skill sets, an extensive coordination and communication mechanism and an organizational structure that supports global integration and an executive leadership that can clearly articulate a global vision. In Level 5, there is integration, which often involves the coordination of design and procurement activities, occurs during the development of new products and technology as well as during the sourcing of items or services to fulfill existing demand. This is the highest level of global sourcing.

Porter identified the driving forces of global sourcing. According to Porter's generic strategies, the competitive strategies can be divided into low-cost strategy and product-differentiation strategy. Both of these are highly related to global sourcing strategy. There is no doubt that the search for lower costs has been the greatest driver of global sourcing. Other factors include a search for higher quality, greater material availability, and access to product and process technology (e.g., Monczka, Trent, \& Petersen, 2008; Kotabe, 1998).

Stability of currency enables the international trade to be easier while instability makes it more complex and introduces risk. If trade amounts to tens of millions of dollars, a $0.5 \%$ deviation of exchange rate could affect the effectiveness of global sourcing strategy and profitability of the whole supply chain. Moreover, $4 \%$ deviation could result in a disastrous end (Cook, 2006). Procurement leaders are not expected to be experts in currency strategy but as with most other areas of business skill, they need to know who to turn to for advice. In this case, the company treasury will be the source of expert knowledge on international currency rates.

Logistics in global sourcing refers to plenty of additional problems such as transportation delays, bordercrossing procedures and longer inventory management (Boyce, 1999; Bradley, Thomas, Gooley, \& Cooke, 1998). Logistics involves integration of information, transportation, inventory, warehousing, material handling and packaging. Logistical management includes the design and administration of systems to control the flow of materials, work in process and finished inventory to support business unit strategy. The overall goal of logistics is to achieve a targeted level of customer service at the lowest possible total cost.

The special regulations promulgated by governments also influence global sourcing directly and indirectly and often make it complicated. The main regulations impacting global sourcing are tariffs and quotas (Sowinski, 1999). Tariffs are taxes that government imposes on commodities, one of the methods that governments used to control economic activity. Tariffs affect global sourcing negatively. Tariffs are effective and widely used to protect the local industries from foreign competition. Non-tariff barriers (NTBs) to trade include import quotas, special licenses, unreasonable standards for the quality of goods, bureaucratic delays at customs, export restrictions, limiting the activities of state trading, export subsidies, countervailing duties, technical barriers to trade, sanitary and phyto-sanitary measures, rules of origin, etc.

Cultural issues in global sourcing are manageable, but it still should be recognized as a concern that must be dealt with (Cook, 2006). There are cultural points to consider when doing business negotiations globally such as; a firm handshake accompanied with smile and appropriate greeting is normal in a business setting, direct eye contact is important, some women may not shake hands with man although this is becoming less common. Some people stand very close when conversing, always use surnames and wait to be invited to use someone's first name, business cards are exchanged on the initial meeting at the very start, initial meetings should be used to build a relationship and established trust, although time is of the essence be patient, communication style tends to be tuned to people's feelings, lastly never openly criticize anyone (Kwinstessential 2008).

George et al, (2009) in his journal, The Essence of Global Sourcing, concludes that the establishment of global sourcing is an exciting endeavor. Many companies source internationally for proven lower costs; then look to benefit from higher quality and lower total costs; still others want to be able to satisfy local content requirements to support its sales commitments.

\section{Objectives Of The Study}

i. To examine the effect of currency fluctuation on adoption of global sourcing

ii. To assess the effect of complicated logistics on adoption of global sourcing

iii. To assess the effect of tariffs and non-tariff barriers on adoption of global sourcing

iv. To examine the effect of culture and language differences on adoption of global sourcing

\section{Research Methodology}

This study employed a descriptive survey research design because it was appropriate. First descriptions are informative; secondly descriptions are the starting point for identifying variables and building hypothetical constructs that can be tested using other methods. Thirdly, description is sometimes the only way to study a behavior or situation, because it is either physically or ethically impossible to produce it in an experiment (Heiman, 1999). 
The population of interest in this study consisted of 130 respondents covering employees of Tuskys supermarket selected randomly. Tuskys supermarkets global source food items, home care items, beauty and hygiene items, household and entertainment items. To ensure fair representation and generalization of findings to the general population, probability sampling technique was used. In probability sampling, the study administered stratified sampling procedure. The population elements were divided into three non-overlapping groups, and then the researcher administered the simple random sampling on the different strata.

These non-overlapping groups were; top management, middle level management and low level management. This ensured that each stratum of the sample frame was represented. It also avoided the bias that could occur if simple random sampling was employed alone. The researcher selected 65 employees out of 130 working employees targeted representing $50.0 \%$ of the total population. This sample size mainly constituted of officers and their assistants working at Tuskys supermarkets.

In this study, both primary and secondary data was gathered. Secondary data was collected from the past research works, internet, relevant journals, magazines, and newspapers. Primary data was collected using questionnaire and was used to give an official opinion or position of the current respondents towards the adoption of global sourcing. The questionnaires were structured in such a way that they elicited specific information from the respondents. The questions comprised of multiple choice, open-ended and dichotomous questions.

A pilot test was carried out on 10 respondents who were different from the main respondents to detect any weaknesses in the design and instrumentation. Piloting was vital in establishing the validity of the research instrument. Data collected was analyzed both quantitatively and qualitatively. Before analyzing the data, it was first edited, coded and entered into excel worksheets, where the researchers used SPSS to analyze the data. To ensure accuracy of the data, frequency distribution tables, bar charts and pie charts were used to present the results for easier understanding and interpretation using inferential statistics. In addition common themes were captured through content analysis.

Data analysis was done using descriptive statistics and inferential statistics. The research was guided by the work of Mugenda, (1999) who suggested that researchers need to assure their respondents of confidentiality and also the need to be truthful in their reporting without letting one's opinion misled the respondent which would be a key source of biasness in any given research.

\section{Result And Discussion}

The main reason for the study was to investigate the effects of different factors key among them currency fluctuations; complicated logistics; tariff and non-tariff barriers; and cultural and language differences have on the adoption of global sourcing. These factors were rated in a scale of 1 to 5 , with $1,2,3,4$ and 5 representing strongly disagree, disagree, neutral, agree and strongly agree respectively. These ratings were represented in tabular form and the mode for each factor was indicated showing the scale of the majority of the respondents.

Table 1 below gives a summary of descriptive results on how each of the factors in the study affects the adoption of global sourcing by Tuskys supermarket. The effects of currency fluctuations had mode of 5 an indication that majority of the respondents strongly agreed that fluctuation of currency rates against major world currencies had effects on the adoption of global sourcing. The study showed that the risk of fluctuation in currency exchange rate affects the adoption of global sourcing as shown by $86 \%$ respondents (agree and strongly agree); high exchange rates discourage importation of goods because of the high prices. The local currency looses its purchasing power against the hard currencies thus resulting to high prices on imports. All this indicates that fluctuations in currency exchange rates have negative effects on the adoption of global sourcing among Tuskys supermarkets. Most respondents agreed that at some point they had to replace a preferred vendor because of changes in exchange rates, i.e. switching from one sourcing destination to another. The stability of currencies makes global sourcing easier while instability makes it more complex and introduces the element of risk.

The findings further showed that majority of the respondents agreed that complicated logistics had effects on the adoption of global sourcing process since the factor had a mode of 4 . A majority of $90 \%$ agreed that they had adverse logistical issues in port clearance delays, cost of logistics, longer inventory management, as well as handling of return goods and containers. To help them to overcome the challenges from logistics in global sourcing, the utilization of third party logistics have been quite essential. An outcome we can see clearly is the preference of utilization of third-party logistics by a massive of the respondents interviewed. According to respondents frequency, four out of five times, the Tuskys supermarket uses third party logistics in global sourcing. It is also observed, to cope with longer lead time, maintaining high-level of inventory is unavoidable in global sourcing although not very often.

The tariff and non-tariff barriers had mode of 4 , showing they affect global sourcing. Most of the respondents suggested non-tariff barriers are the most common, and should be abolished for effective global 
sourcing. Some of the non-tariff barriers like unreasonable standards quality of goods, bureaucratic delays at the custom, road blocks and barriers should be lowered or abolished to facilitate global sourcing. However, the study findings showed that tariff/taxation barriers have mild impact on global sourcing as most of the respondents were neutral on this issue. Most countries are no longer using tariffs in controlling trade, they hide behind non-tariff barriers to manipulate and control global trading activities. Local supermarkets have to suffer the lower competitive advantages caused by expensive importing costs caused by tariffs and non-tariff barriers encountered during global sourcing.

Cultural and language differences had no effects on the adoption of global sourcing since majority of the respondents strongly disagreeing with a mode of 1 . Since $98 \%$ (strongly disagree and disagree) of the respondents said that, cultural issues did not lead to instability of the relationship between them (Tuskys) and their suppliers. The respondents argued that cultural and language differences didn't affect the business transactions since there existed middlemen and establishment of a common language to facilitate the trade. Further, miscommunication with a foreign supplier does not lead to conflict or supply of wrong products, and different cultures and languages between different countries had no effect on the process according to majority of the respondents. With the motivation of economic globalization and positive cultural communication, cultural problems have been overcome when implementing global sourcing.

Table 1: Summary of factors affecting the adoption global sourcing

\begin{tabular}{|c|c|c|c|c|c|c|c|}
\hline & & $\begin{array}{l}\text { Strongly } \\
\text { Disagree }\end{array}$ & Disagree & Neutral & Agree & $\begin{array}{l}\text { Strongly } \\
\text { Agree }\end{array}$ & Mode \\
\hline $\begin{array}{l}\text { Effects of currency fluctuations on } \\
\text { adoption of global sourcing }\end{array}$ & $\begin{array}{l}\mathrm{f} \\
\%\end{array}$ & $\begin{array}{l}1 \\
2.0\end{array}$ & $\begin{array}{l}0 \\
0.0\end{array}$ & $\begin{array}{l}6 \\
12.0\end{array}$ & $\begin{array}{l}14 \\
28.0\end{array}$ & $\begin{array}{l}29 \\
58.0\end{array}$ & 5 \\
\hline $\begin{array}{l}\text { Effects of complicated logistics on } \\
\text { adoption of global sourcing }\end{array}$ & $\begin{array}{l}\mathrm{f} \\
\%\end{array}$ & $\begin{array}{l}0 \\
0.0\end{array}$ & $\begin{array}{l}0 \\
0.0\end{array}$ & $\begin{array}{l}5 \\
10.0\end{array}$ & $\begin{array}{l}24 \\
48.0\end{array}$ & $\begin{array}{l}21 \\
42.0\end{array}$ & 4 \\
\hline $\begin{array}{l}\text { Effects of tariffs and non-tariffs barriers } \\
\text { on adoption of global sourcing }\end{array}$ & $\begin{array}{l}\mathrm{f} \\
\%\end{array}$ & $\begin{array}{l}0 \\
0.0\end{array}$ & $\begin{array}{l}0 \\
0.0\end{array}$ & $\begin{array}{l}8 \\
16.0\end{array}$ & $\begin{array}{l}42 \\
84.0\end{array}$ & $\begin{array}{l}0 \\
0.0\end{array}$ & 4 \\
\hline $\begin{array}{l}\text { Effects of cultural and language } \\
\text { differences on adoption of global } \\
\text { sourcing }\end{array}$ & $\begin{array}{l}\mathrm{f} \\
\%\end{array}$ & $\begin{array}{l}34 \\
68.0\end{array}$ & $\begin{array}{l}15 \\
30.0\end{array}$ & $\begin{array}{l}0 \\
0.0\end{array}$ & $\begin{array}{l}1 \\
2.0\end{array}$ & $\begin{array}{l}0 \\
0.0\end{array}$ & 1 \\
\hline
\end{tabular}

Where; $\mathrm{n}=50, \mathrm{f}$ is frequency, and, $\%$ is percentage.

\section{Conclusions}

In conclusion we observe that, three out of the four factors studied affects the adoption of global sourcing among Tuskys supermarkets. The only exceptional factor was cultural and language differences, which had no effects on the adoption of global sourcing. Complicated logistics was rated high at $90 \%$, currency fluctuations was second at $86 \%$, whereas the tariff and non-tariff barriers was third at $84 \%$. From the results of the study one can conclude that the adoption of global sourcing is not effective due to various factors including and not limited to complicated logistics, currency fluctuations, and the tariff and non-tariff barriers. However, adopting global sourcing is a long, complicated process and there are numerous setbacks to be overcome in the light of the factors analyzed by this study.

There is need for a mindset shift. Tuskys supermarkets need to focus globally and develop a truly global approach across different departments for the best overall results, and to overcome those hindering factors. They should invest in new global sourcing strategies while monitoring the dynamics of global sourcing closely. For Tuskys supermarket, it has to face these factors and challenges as well, and it should pay more attention to the challenges from logistics capabilities, selecting foreign sources, monitoring international currencies movements, and dynamism of global markets. In conjunction with other industrial players they should petition the government for the relaxation of bureaucratic importation and port regulations, as well as reducing tariff and non-tariff barriers.

Tuskys supermarkets managers should also consider elevating the position of their global sourcing offices and officers to a more centralized position within the organization in order to effectively coordinate global sourcing as part of their overall procuring strategy. All in all, the business processes of pursuing global sourcing for Tuskys supermarkets are showing both opportunities and challenges, which is also significant and meaningful for the worldwide globalization. To be successful, Tuskys must treat global sourcing as a significant project with its own investment, risks, costs and benefits. They must begin to look for new ways to differentiate themselves through their global sourcing activities, either through cost, quality, brand or environmental approaches. 


\section{Acknowledgements}

I would like to express special and sincere gratitude to each and everyone who gave invaluable advice on how to go about this proposal. I applause the immense support and guidance accorded by the supervisor Dr. Mike Iravo, without whom this work would not have been concluded. Besides my supervisors I wish to recognize the contributions of the following other lecturers of Entrepreneurship and Procurement Department for their encouragement in the whole exercise namely Professor G.S Namusonge the chairman BPS, Dr. E Mukulu and Dr. Jane Gathenya.

\section{References}

[1]. Boyce, C., Bradley, P., Thomas, J., Gooley, T., Cooke, J.A. (1999, Nov. 29). Going up. Traffic World, pp. 5.

[2]. Cook, T. A. (2006). Global Sourcing Logistics: How to Manage Risk and Gain Competitive Advantage in a Worldwide Marketplace. Amacom.

[3]. George L. Harris, C.P.M. (2009). The Essence of Global Sourcing. Cambridge, MA.

[4]. Jinsook Cho, Jikyeong Kang, (2001) "Benefits and challenges of global sourcing: perceptions of US apparel retail firms", International Marketing Review, 18(5), pp.542 - 561.

[5]. Kenya Institute of Management. (2009). Fundamentals of management research methods. ${ }^{\text {st }}$ edition. Macmillan publishers limited.

[6]. Mugenda O.M. \& Mugenda, A.G. (1999). Research Methods: Quantitive and Qualitative Approach. African center for technological studies Publishers. Nairobi.

[7]. Robert M. Monczka, Robert J. Trent, (1991) "Evolving Sourcing Strategies for the 1990s", International Journal of Physical Distribution \& Logistics Management, 21(5), pp.4 - 12.

[8]. Sowinski, L. L. (1999). Legal issues for shippers: what you don't know can hurt you. World Trade, pp. 56-58.

[9]. Trent, R. J., \& Monczka, R. M. (2005). Achieving excellence in global sourcing. MIT Sloan Management Review, pp. 24-32. 